\title{
PVT1 wt Allele
}

National Cancer Institute

\section{Source}

National Cancer Institute. PVT1 wt Allele. NCI Thesaurus. Code C54422.

Human PVT 1 wild-type allele is located in the vicinity of 8 q24.21 and is approximately 307 $\mathrm{kb}$ in length. This allele, which encodes Pvt1 oncogene long non-coding RNA, may play a role in the regulation of the expression of the MYC gene. Overexpression of the PVT 1 gene is associated with the development of Burkitt lymphoma, breast and ovarian cancers, acute myeloid leukemia and Hodgkin lymphoma; variations in this gene are associated with end-stage renal disease attributed to type 1 diabetes. 